\title{
Analysis of the Difficulties of the Mathematical Creative Thinking Process in the Application of Problem Based Learning Model
}

\author{
Esron P. Purba \\ Postgraduate Program, Mathematics Education \\ Universitas Negeri Medan \\ Medan, Indonesia \\ Corresponding email: esronparjuanganpurba@yahoo.co.id \\ Bornok Sinaga \\ Postgraduate Program, Mathematics Education \\ Universitas Negeri Medan \\ Medan, Indonesia \\ Mukhtar \\ Postgraduate Program, Mathematics Education \\ Universitas Negeri Medan \\ Medan, Indonesia \\ Edy Surya \\ Postgraduate Program, Mathematics Education \\ Universitas Negeri Medan \\ Medan, Indonesia
}

\begin{abstract}
This research is a qualitative descriptive research. Data analysis has been used is Miles and Huberman Methods. The result of the research shows that: the level of ability of mathematical creative thinking is at the level of 'medium' creative thinking ability; at the preparatory stage, students have prepared themselves to solve problems by learning to think, seek answers; at the incubation stage, searching and gathering data/information; at the stage of illumination, raises new ideas; until at the verification/evaluation stage; the analysis of the difficulty of the mathematical creative thinking process of this research is the difficulty in applying the principles and problem solving. Then, there is the inability to detail problem-solving characterized by the difficulty of principles and procedures that include the inability to plan the settlement, the inability to engage in the discovery, the inability to abstract patterns, the inability to express the meaning and not apply the principle. In addition, the inability to give many ideas, the inability to solve problems from different perspectives, the inability to solve problems in one's own way, and the inability to develop or detail in a situation; students activity are effective so that learning by applying Problem Based Learning Model provides an opportunity for students to explore various answers and ways of completion with attention to aspects of fluency, flexibility, originality, and elaboration.
\end{abstract}

Keywords—creative thinking, problem based learning

\section{INTRODUCTION}

Mathematics is very important. Mathematics with its various roles makes it a very important science and one of the role of mathematics is as a tool of thinking to deliver students to understand the concept of mathematics that is being studied. Things that need to be developed in learning mathematics is 1) mastery of mathematical concepts; 2) problem-solving ability; 3) reasoning and communication skills; 4) the ability to think creatively and innovatively[1]. Furthermore that "Education 2030 will ensure that all the creativity a solid foundation of knowledge, develop creative and critical thinking and collaborative skill and build curiosity, courage, resilience"[2]. Then, the problems faced in learning mathematics increasingly complex and lead to the goal of $21 \mathrm{st}$ century creative education. Thus, the ability to understand mathematical and creative thinking is needed, in order to be able to solve mathematical problems. In addition, learning is aimed at developing the potential of learners to have the ability to live as a creative and innovative person who has the ability to search, process, construct, and use knowledge. So, it is necessary to have the ability to think creatively mathematically.

Creative thinking is one of human ability that plays an important role in life. This ability is much based on intellectual ability, such as intelligence, talent, and learning ability and supported also by affective and psychomotor 
factors. So that creativity plays an important role in a series of high-level mathematical thinking. Mathematical creative thinking indicators include fluency, flexibility, originality, and elaboration. Fluency in problem solving refers to the ability of students to give answers to problems more than two ways and smoothly. Flexibility refers to the ability of students to solve problems in different ways so that they look at changes in approaches when responding to commands. Originality refers to a student's ability to answer a problem with several different but valuable answers or one unusual answer made by a student to his or her level of knowledge so that authenticity is a novelty of ideas made in response to orders. While elaboration emphasizes the ability to develop or detail a situation in detail in solving the problem.

Table 1. Step Principle Problem Based Learning Model

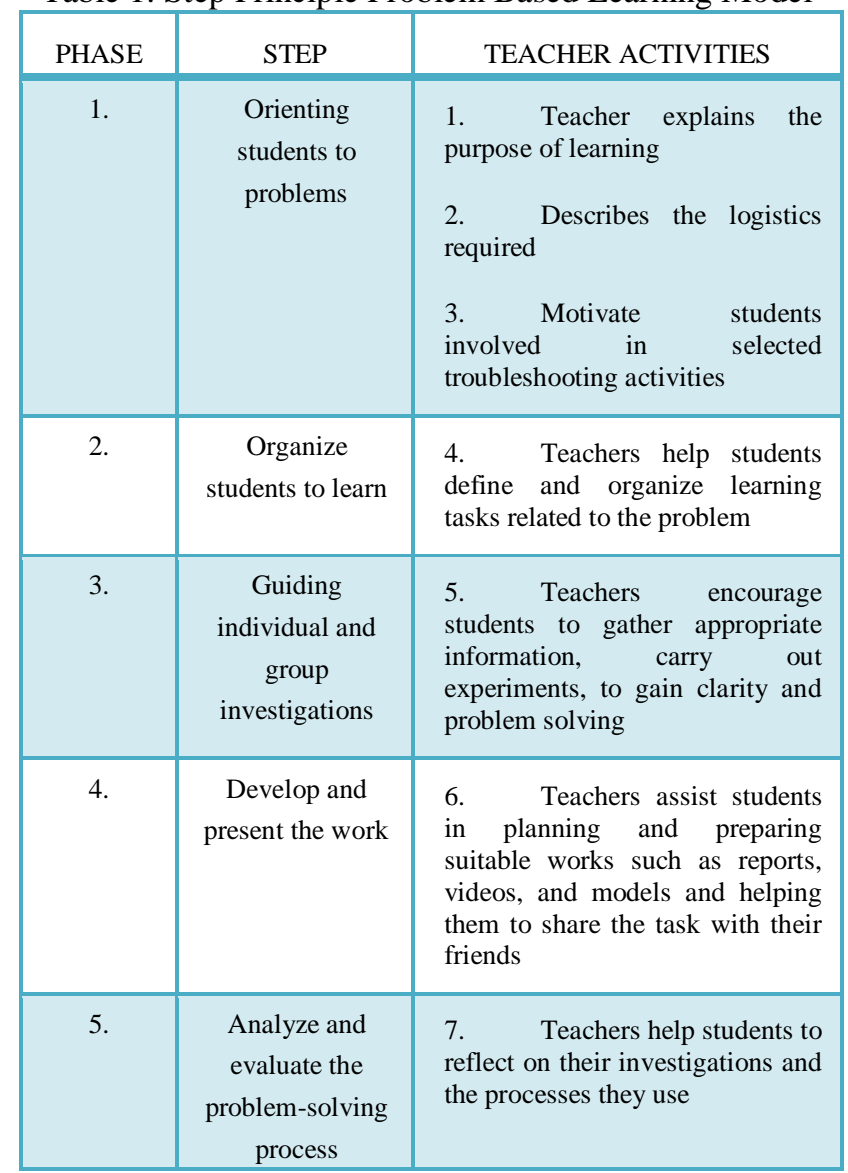

To cultivate students' mathematical creative thinking skills, teachers should seek learning by using learning models that can provide opportunities and encourage students to learn independently. Please note that each student has different abilities in understanding mathematics. From a group of randomly selected students will always encounter students who have high ability, moderate, and low[3]. Differences in abilities possessed by students are not merely innate, but can also be influenced by the environment. Therefore, the selection of learning environments, especially the learning model becomes very important to be considered, the choice of learning model must be able to accommodate students' heterogeneous math skills so as to maximize student learning outcomes. There are many models of learning that can be used in the effort to develop the mathematical creative thinking abilities, one model of learning that allegedly would be in line with the characteristics of mathematics and curriculum expectations prevailing at this time is a problem based learning model (Problem Based Learning or PBL). This model is an approach to teaching students on authentic problems (real) so that learners can construct their own knowledge, foster high skills and inquiry, to independent the learners, and increase self confidence[4].

Learning by PBL is one of student centered learning while teacher as facilitator. "PBL is an instructional (and curricular) learner-centered approach that empowers learners to conduct research, integrate theory and practice, and apply knowledge and skills to develop a viable solution to a defined problem"[5]. In this PBL the students also developed their ability in thinking high level required in learning mathematics. This is corresponding with Arends that PBL is a learning approach where students work on problems that authentic with the intention to construct their own knowledge, develop inquiry and thinking skills a higher level, develop independence and confidence[4]. In the PBL model proposed the main steps of learning proposed[4]; [6]; [7] in table 1.

\section{METHODS}

This research using descriptive qualitative approach. Qualitative research is a study that intends to understand what phenomena experienced by research subjects such as behavior, perception, motivation, action, etc., holistically, and by way of description in the form of words, words and languages, to a specific, natural context and by utilizing various natural methods[8]. Suggests that qualitative research is a study whose findings are not obtained through statistical procedures or counts[9]. To know the process of students' mathematical creative thinking, the guideline used is the creative process developed by Wallas covering four stages: 1) preparation, 2) incubation, 3) illumination, and 4) verification. In the first stage someone prepares to solve the problem by collecting relevant data, and looking for an approach to solve it. In the second stage, a person seems to break away temporarily from the problem. This stage is important as the beginning of the process of inspiration which is the starting point of a new invention or creation from the preconscious region. In the third stage, a person gets a problem solving followed by the emergence of inspiration and ideas that start and follow the emergence of new inspirations and ideas. In the last stage is the stage of someone testing and examining the problem solving to reality. Here needed critical thinking (convergent). At this stage of verification, a person does a creative thinking followed by critical thinking.

This data collection process includes the process of entering the location of research as well as being in the location of research and collect research data. Methods of data collection is to implement learning, test students' creative thinking ability mathematically, interviews to students and teachers, observation, and documentation. The mechanism used in this research includes three stages, namely (1) stages of preparation of learning tools and research instruments; (2) 
the stages of validation and testing of study tools and research instruments; (3) stages of the implementation of research and data analysis. Each stage is designed in such a way as to obtain valid data for the purpose of research. While the data analysis process used Miles and Huberman method includes data collection, data reduction, display data, and conclusion.

\section{RESULT}

The student's answer process deals with the object of mathematics. The process of mathematical creative thinking is described based on the learning process applied using the PBL. At the time of learning, trained, and familiarized, even cultivated process of mathematical creative thinking. It turns out that students are increasingly able to think to seek answers with various answers. Firstly the students smoothly answer the question by dividing the square into two rectangles, then given scaffolding so as to divide the square into two triangles. The process tries to get used so students find ways to divide the square with the help of a semicircle.
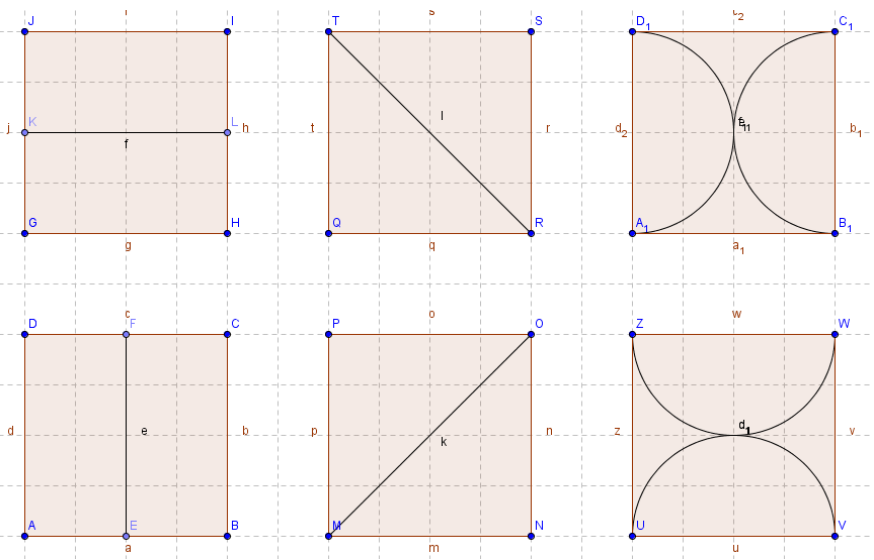

Fig 1. Sketch of student's answer process

Thus, based on the stage of the mathematical creative thinking process, it is concluded that students have prepared themselves to solve problems by learning to think, seek answers, ask people and so on (preparation stage). Activity by searching and collecting data/information (incubation stage), raises a new idea (illumination stage), until activity of students filled properly (verification/evaluation stage).

The importance of the process of mathematical creative thinking needs to be reviewed from various difficulties in mathematics learning. As research focused literature review from 2004 to 2014 with the search of over 110 research studies regarding creative problem solving[10]. In addition, learning through the curriculum should be able to think high level or often called HOTS (Higher Order Thinking Skilss) which includes 4C namely Colaborative, Comunicative, Critis, and Creative. By accustomed to creative thinking especially in mathematics achieved a good level of thinking so as to reduce student learning difficulties.

Learning difficulties are conditions that create obstacles in one's learning process. The difficulty of learning mathematics of students is shown by the existence of certain barriers to achieve learning outcomes, so that ultimately can lead to achievement of learning that achieved differently under the proper. Analysis of difficulties in solving story problems can occur because of difficulties in understanding the problem, the difficulty of planning the settlement, the difficulty of carrying out problem solving, and the difficulty of making the conclusion of the answer. Successful teachers can relatively easily explore the abilities, values/attitudes, and interests of their students. Thus the teacher will be able to align or modify the activities so that students can understand the teaching materials (rectangular material) developed by teachers to achieve the expected competencies. If the patient is not well, or the student is experiencing an obstacle, then the first time it is known, the teacher should see it as a problem to be solved. Student failures should not be viewed as an ordinary thing in mathematics. The encouragement of teachers to solve student problems is one of the elements in teacher professional development[11].

The difficulty of solving story problems relates to the students' mathematical creative thinking sustainable with the understanding of mathematical objects. In understanding the problem students already understand the facts and concepts of mathematics but the students have not worked according to the guidelines of mathematical creative thinking. For example: already answered correctly even if only one way. In planning the completion of students using the concept of sober so that students allow not to get to the process of better mathematical creative thinking. Students just get to the understanding who know the facts, concepts, and principles but can not elaborate so should be familiarized interact with friends so that the group of children can solve by way of cooperation. This is in accordance with the statements that "... students should not only know the concepts and procedures of mathematics is created and used"[12]

On the difficulty of carrying out problem-solving planning students can not understand the origins of a principle so as not to be able to solve problems from different angles. Example: know about the formula of searching the circumference and the widespread widescreen even the circumference and the area of the circle but not all can divide the two squares into two equal parts of the area rectangular, triangular, or combined with the circle. Students know what the formula is and use it, but do not know where or in what context the principle is used. While in the difficulty of conclusion the answer is seen when the students return the answer. Students may not smoothly use surgery or procedures due to incomplete knowledge that hampers students' ability to solve math problems, while the lessons continue in stages. Factors that cause student learning difficulties vary widely. Not all factors are discussed in this study, but more likely to review some students 'mistakes in solving mathematical problems, especially the ability of students' mathematical creative thinking to create a level of mathematical creative thinking.

\section{CONCLUSION}

Based on the results of analysis and discussion obtained some conclusions as follows: the level of mathematical creative ability of 50 students with 'very low' creative thinking ability as much as $38 \%$, 'low' creative thinking ability as much as $4 \%$, 'moderate' creative thinking ability as much as $42 \%$, 
'high' creative thinking ability as much as $12 \%$, and 'very high' creative thinking ability as much as $4 \%$. After the student answer process is described, it is concluded that the students have prepared themselves to solve the problem by learning to think, and seeking answers (preparation phase), searching and collecting data/information (incubation phase), creating new ideas (illumination phase) and the learning goes smoothly (verification/evaluation phase). Analysis of difficulties in the process of mathematical creative thinking in solving the problem related to the test of students' mathematical creative thinking ability occurs because of difficulties in understanding the problem, the difficulty of planning the settlement, the difficulty of solving the problem, and the difficulty of making the conclusion of the answer. So in general, the difficulties in the process of mathematical creative thinking in this study is the difficulty in applying the principle and detailing problem solving. The overall percentage of student activity is still at the ideal time tolerance interval.

\section{DISCUSSION}

Mathematics learning through the PBL instills an active awareness of individuals and groups and develops students' mathematical creative thinking skills. Implementation of learning also provides the ability to understand facts and mathematical concepts. Developing learning with an understanding of mathematical objects and being involved through a mathematical creative thinking process provides an opportunity for students to explore various answers and solutions by looking at aspects of fluency, flexibility, originality, and elaboration.

\section{SUGGESTION}

Based on the above conclusions, the following suggestions are given:

1) Mathematics learning in primary and secondary education through the development of students' mathematical creative thinking (HOTS or Higher Order Thinking Skilss) is already encouraged but needs to be familiarized and even cultivated.
2) In each lesson, teachers should create an atmosphere of learning that gives students the opportunity to express mathematical ideas in their own language and ways so that they are more daring to argue, more confidently and creatively.

3) Teachers should provide greater opportunities for students to explore their own abilities so that at the time of discussion the group has the capital to discuss so that the discussion created more directed.

4) Needs socialization by schools to think mathematically creative students are not foreign so that its application more sustainable which certainly has implications on the increase of student achievement in the mastery of mathematics material.

\section{REFERENCES}

[1] Ditjen GTK Kemdikbud. Guru Pembelajar, Modul Matematika SMP. Kelompok Kompetensi E, 2016.

[2] Framework for Action. Education 2030 Incheon Declaration and Framework for Action. Republic of Korea: Unesco, 2016.

[3] Russefendi. Pengantar kepada Guru Membantu Mengembangkan Kompetensinya dalam Mengajar Matematika untuk Meningkatkan CBSA. Bandung: Tarsito, 1991.

[4] Trianto. Mendesain Model-Model Pembelajaran Inovatif-Progresif. Jakarta: Kencana Prenada Media Group, 2011.

[5] Savery, J. R. Overview of Problem-based Learning: Definitions and Distinctions, Interdisciplinary Journal of Problem-Based Learning, Volume.1 Issue 1, 2006.

[6] Sinaga, Bornok. Buku Model PBM-B3. Surabaya: PPs Universitas Negeri Surabaya, 2007.

[7] Rusman. Model-Model Pembelajaran: Mengembangkan Profesionalisme Guru. Jakarta: Rajawali Pers, 2014.

[8] Moleong, Lexy J. Metodologi Penelitian Kualitatif. Bandung: PT. Remaja Rosdakarya Offset, 2016.

[9] Strauss, Anserm dan Corbin, Juliet. Dasar-Dasar Penelitian Kualitatif. Yogyakarta: Pustaka Pelajar, 2003.

[10] Sophonhiranraka. Factor Affecting Creative Problem Solving in the Blended Learning Envoronment: a review of the literature. Thailand: Elsevier LTd, 2014.

[11] Widdiharto, dkk. Diagnosis Kesulitan Belajar Matematika dan Alternatif Proses Remidinya. Yogyakarta: PPPPTK Yogyakarta, 2008.

[12] Romberg dan Fennema. Mathematics Classrooms That Promote Understanding. New Jersey: Lawrence Erlabaum Associates, Publisher, 2009. 